
053620180210

\title{
Activity of antioxidative enzymes in watercress and Chinese cabbage plants grown under hydroponic system with brackish water
}

\section{Raquele M Lira; Ênio FF Silva; Lilia Willadino; Ronaldo A Oliveira Filho; Gilvany R Andrade}

Universidade Federal Rural de Pernambuco (UFRPE), Recife-PE, Brazil; raquelelira@gmail.com; willadino.lilia@gmail.com; rcnaldoalvesfoto@hotmail.com; gilvany0710@gmail.com

\begin{abstract}
Underground water reserves in Semiarid Region present high salinity levels; however, scarcity of resource compels farmers to use this water for conventional agriculture. Biomass production and activity of the antioxidative defense system of Chinese cabbage and watercress were evaluated in plants grown under hydroponic NFT system with brackish water. The experimental design was completely randomized, with four replications and five water salinity levels (1.95; $3.37 ; 4.48 ; 6.82$ and $7.51 \mathrm{dS} \mathrm{m}^{-1}$ ), obtained by an increasing addition of $\mathrm{NaCl}$ into the local water supply and nutrient salts for preparation of nutrient solution. Both watercress and Chinese cabbage plants decreased in fresh and dry shoot biomass, in relation to increase of salinity in solution, considering that these losses were marked in Chinese cabbage crop. The antioxidative defense system was activated in both evaluated species. Superoxide dismutase (SOD) and peroxidase (POD) increased their activity in relation to salinity increase in the solution. Watercress presented higher POD activity and was able to maintain catalase (CAT) and total phenols higher than control in most treatments, resulting in better adaptation to salt stress.
\end{abstract}

Keywords: Naturtium officinale, Brassica pekinensis, superoxide dismutase, ascorbate peroxidase, catalase.

\section{RESUMO}

Atividade de enzimas antioxidativas em agrião e couve chinesa cultivadas em sistema hidropônico com águas salobras

Em regiões semiáridas, as reservas de águas subterrâneas apresentam elevadas concentrações salinas, porém, a escassez deste recurso obriga agricultores a utilizarem este tipo de água na agricultura convencional. Objetivou-se avaliar produção de biomassa e atividade do sistema de defesa antioxidativo de plantas de couve chinesa e agrião cultivadas em sistema hidropônico NFT com uso de águas salobras. Foi adotado o delineamento experimental inteiramente casualizado, com quatro repetições e cinco tratamentos referentes a níveis de salinidades da solução nutritiva $(1,95 ; 3,37 ; 4,48 ; 6,82$ e 7,51 dS m $\mathrm{m}^{-1}$ ), obtidos pela adição crescente de $\mathrm{NaCl}$ na água e de sais nutrientes para o preparo da solução nutritiva. Para as plantas de agrião e de couve chinesa houve reduções das biomassas fresca e seca da parte aérea em função do aumento da salinidade na solução, sendo estas perdas mais acentuadas na cultura da couve chinesa. $\mathrm{O}$ sistema de defesa antioxidativo foi ativado nas duas espécies em estudo. As enzimas superóxido dismutase (SOD) e peroxidase (POD) aumentaram sua atividade em função do aumento da salinidade na solução. O agrião apresentou maior atividade da POD e conseguiu manter a catalase (CAT) e fenóis totais maiores do que o controle na maioria dos tratamentos analisados conferindo-lhe assim, maior adaptação ao estresse salino.

Palavras-chave: Naturtium officinale, Brassica pekinensis, superóxido dismutase, ascorbato peroxidase, catalase.

\section{Received on May 3, 2017; accepted on January 11, 2018}

$I^{\mathrm{n}}$ Semiarid regions where evapotranspirometric rates are high and rainfall indexes low, irrigation is necessary in order to ensure crop productivity. However, due to the low availability of good quality water, the use of brackish water, commonly found in shallow wells of the region, turns out to be a good option (Araujo et al., 2016).

Irrigation using brackish water can represent risks to the environment, causing soil salinization and, as consequence desertification, causing damages to agricultural production.
Ayers \& Westcot (1999) state that salinity and sodicity effects on soil can cause disintegration, an increase in apparent density, water retention and less water infiltration due to excess of sodium ion. High salt concentrations decrease the osmotic potential of soil solution, which decreases water and nutritional availability for plants; moreover, toxic effects with specific ion accumulation, functional disorders and injuries in crop metabolism can be noticed (Silva et al., 2009; Taiz \& Zeiger, 2009).
Salinity can promote a stressful condition which causes metabolic changes in plants and can trigger oxidative stress, characterized by superproduction of oxigen-reactive species (ROS). Plants have a complex antioxidative system consisting of antioxidant enzymes and metabolites able to prevent accumulation of ROS and oxidative stress (Barbosa et al., 2014). Enzymes of the antioxidant system are quite sensitive to abiotic stress conditions, also serving as stress signals. Some stood out among 
them: superoxide dismutase (SOD), catalase (CAT), ascorbate peroxidase (APX), and peroxidases (POD). SOD considerably accelerates $\mathrm{O} 2 \cdot-$ which leads to formation of another ROS, $\mathrm{H}_{2} \mathrm{O}_{2}$. Hydrogen peroxide is a strong oxidant and cannot be accumulated in cells. CAT acts by converting $\mathrm{H}_{2} \mathrm{O}_{2}$ to water and molecular oxygen, whereas APX and POD require a reductant to convert $\mathrm{H}_{2} \mathrm{O}_{2}$ to water (Miller et $a l ., 2010)$. The increased antioxidant enzyme activity and concentrations of low-molecular-weight metabolites such as ascorbate and glutathione can prevent or reduce damage caused by ROS to nucleic acids, proteins and membranes, maintaining redox homeostasis (Foyer $\&$ Noctor, 2009).

An alternative technique to use underground brackish waters is the hydroponic cultivation system (Santos et al., 2010). This technique consists of substituting soil for an aqueous solution containing only mineral elements defined as essential for plants (Silva $e t$ al., 2016). In hydroponic cultivation system, nutrients supplementation through water, results in reduced losses that normally occur when growing in soil (volatilization, leaching and fixation), besides having advantages of lower use of water and higher efficiency in its use. Besides, there will be better use of area, higher productivity, reduced vegetative cycle, as well as possibility to control the disposal into environment (Ferreira et al., 2017; Santos et al. 2010). Thus, direct contact of the saline effluent with environment is suppressed, avoiding salinity in adjacent areas.

Among several hydroponic cultivation systems, NFT (laminar flow of nutrients) stands out. NFT is a closed system in which the culture medium circulates through the system intermittently or continuously, depending on how it is established. In this system, plant response to salinity is better when compared with conventional system, due to the fact that salinity effects on crops are reduced because of low influence of matric potential and great water and nutrients availability, guaranteed by high frequency of nutrient solution application (Santos et al., 2016).
In relation to the shorter crop cycle under hydroponic cultivation, the use of brackish water confers great advantage considering shorter period of exposure time to salt stress, resulting in minimization of damage caused to plants when brackish water is used. Taking this into account, vegetables stand out, such as Chinese cabbage and watercress, both belonging to Brassicaceae family, which are important sources of vitamins and minerals, essential for human consumption. Watercress is considered one of the main sources of vitamin A, essential for good vision and for maintaining skin health. This vegetable is also rich in vitamin $\mathrm{C}$ and minerals, has more iron than cabbage and spinach and stalks are rich in iodine (Embrapa, 2011). Chinese cabbage, commercial known in some places as Swiss chard, is an excellent source of folic acid, vitamin A, group-B vitamins and calcium, in addition to providing vitamin $\mathrm{C}$ and minerals such as sodium, potassium, magnesium and calcium (Evangelista et al., 2009).

We evaluated the effect of salt stress on antioxidative defense metabolism and productive capacity of watercress and Chinese cabbage plants grown in hydroponic NFT system.

\section{MATERIAL AND METHODS}

The experiment was installed in Departamento de Engenharia Agrícola, at Universidade Federal Rural de Pernambuco, campus Recife (801'05"S; 3456'48”W; $6.5 \mathrm{~m}$ altitude). The experiment was installed in a greenhouse, $24 \mathrm{~m}$ length, $7.0 \mathrm{~m}$ width, $3.0 \mathrm{~m}$ ceiling height, $4.5 \mathrm{~m}$ central height and $0.2 \mathrm{~m}$ baseboard in reinforced concrete. Cover was in arch type, low density polyethylene film, transparent, anti UV additives, 0.10 $\mathrm{mm}$ thickness; lateral and front walls consisted of anti-aphid screens.

Two experiments were installed in NFT hydroponics system (laminar flow of nutrients), using watercress crop (cv. Folha Larga) in September, 2012 and Chinese cabbage (cv. Natsumi) in October, 2012, submitted to five salinity levels of nutrient solution. A completely randomized design with four replications, totaling 20 experimental units for each crop was used.

Salinity levels, except for control $\left(0.3 \mathrm{dS} \mathrm{m}^{-1}\right)$, were obtained adding sodium chloride $(\mathrm{NaCl})$ into the local water supply $\left(0.3 \mathrm{dS} \mathrm{m}^{-1}\right)$, providing electrical conductivity values of $1.67 ; 3.3 ; 4.71$ and $5.88 \mathrm{dS} \mathrm{m}^{-1}$. After preparing brackish water, nutrients were added according to Furlani (1999), thus the electrical conductivity turned into $1.95 ; 3.37 ; 4.48 ; 6.82$ and $7.51 \mathrm{dS} \mathrm{m}^{-1}$, making these values the treatments of the present study.

Each experimental plot was represented by an independent NFT system, with hydroponic profile and a reservoir with 60 -L nutrient solution capacity.

Watercress and Chinese cabbage were sown in $2 \times 2 \times 2 \mathrm{~cm}$ phenolic foam plates, on September 4, 2012 and October 26, 2012, respectively. For watercress, 12 seeds, and for Chinese cabbage, three seeds per phenolic foam cell were sown. After germination and after four days of sowing, seedlings were placed on greenhouse benches (nursery in NFT system), where, during 15 days, Furlani nutrient solution (1999) at $50 \%$ was applied. Nursery irrigation was controlled by an electronic timer programmed at regular intervals of 15 minutes between irrigation, from 7 a.m. to 6 p.m. From 6 p.m. until 7 a.m., the nutrient solution was recirculated every 2 hours, with duration of $15 \mathrm{~min}$. Six central orifices of the hydroponic profile were considered useful plot. Plantlets were thinned, remaining for watercress crop four plants per cell and for Chinese cabbage crop one plant per phenolic foam cell.

Watercress and Chinese cabbage were harvested 45 and 53 days after sowing (DAS), respectively. After harvests, one part of the plant material was used for biochemical analyses, and another part was used to obtain fresh shoot biomass (BFPA). After that, to obtain dry shoot biomass (BSPA), the material was submitted to a dryer with forced air circulation at $65^{\circ} \mathrm{C}$ until reaching constant mass.

For biochemical analyses, plant material was frozen in liquid 
nitrogen and kept in a freezer at $-20^{\circ} \mathrm{C}$. Authors used $0.5 \mathrm{~g}$ of plant material, which was homogenized under ice-cold condition in phosphate buffer and polyvinylpyrrolidone (PVP), and centrifuged at 10,000x $\mathrm{g}$ at $-4^{\circ} \mathrm{C}$. Supernatant was used to prepare extract and readings were performed using a spectrophotometer. Activity of superoxide dismutase (SOD), ascorbateperoxidase (APX), catalase (CAT), peroxidase (POD) and poliphenoloxidase (PPO) were determined according to methodologies described by Giannopolitis \& Ries (1977), Nakano \& Asada (1981), Vieira \& Fatibello-Filho (1998) and Kar \& Mishra, (1976), respectively. Total phenol content was determined using $0.3 \mathrm{~g}$ fresh plant material, using FolinDeni method and ascorbic acid using the Tillmans method (Bezerra Neto \& Barreto, 2011).

Obtained data were submitted to analysis of variance by $F$ test. Response of the variables related to salt effect was evaluated using regression analysis. The statistical program ASSISTAT was used.

\section{RESULTS AND DISCUSSION}

Watercress and Chinese cabbage plants decreased, significantly, the fresh and dry shoot biomass with salinity increase of nutrient solution. Biomass reduction in relation to unit salinity increase $\left(\mathrm{dS} \mathrm{m}^{-1}\right)$, for watercress was 6.3 and $6.8 \%$; for cabbage was 7.0 and $7.9 \%$ for fresh and dry biomass, respectively (Figure 1A and 1B). These data show the highest adaptation of watercress to salt stress.

Decrease of biomass in plants submitted to salt stress is a consequence of a series of physiological changes, which include reduction in photosynthetic rate, in relation to low soil water potential, as well as due to osmotic and ionic homeostasis of the plant. Cultivation of vegetables in hydroponic system has shown that the magnitude of plant biomass reduction, due to increased salinity, is dependent on species, as seen on roquette and watercress (Alves et al., 2011) and Chinese cabbage (Lira et al., 2015) and other species, as noticed on lettuce (Santos et al., 2010) and roquette (Jesus et al., 2015).

Considering biochemical terms, salt stress causes increase in generation of reactive oxygen species (ROS) and its accumulation leads to damage on cell structures, which may result in plant death (Barbosa et al., 2014). The more effective the activation of antioxidative defense system, the less harmful effects of stress on the plant.

SOD showed increasing activity on plants submitted to salinity (Figure 2A). In watercress crop, the authors noticed, through derived regression equation, that the highest SOD activity occurred at salt level estimated at 3.45 $\mathrm{dS} \mathrm{m}{ }^{-1}$, with a consequent decrease due to increase in electrical conductivity of the nutrient solution. This fact may have occurred due to high salt concentration in the cytoplasm which could have exceeded the capacity of plants to compartmentalize it in the vacuole, causing activity decrease of this enzyme in the plant. The higher enzymatic activity of SOD, as a consequence of plant exposure to salt stress is related to greater tolerance to stress situations in different species (Koca et al., 2007; Ryang et al., 2009). Chinese cabbage showed higher activity of this enzyme in all treatments, even in the absence of salt stress, showing that this is a genotypic characteristic of this crop.

SOD is responsible for dismutation of superoxide $(\mathrm{O} 2 \bullet-)$ into $\mathrm{H}_{2} \mathrm{O}_{2}$ and molecular oxygen, being considered the first line of enzymatic antioxidative defense in plant cell (Foyer \& Noctor, 2009). Hydrogen peroxide $\left(\mathrm{H}_{2} \mathrm{O}_{2}\right)$ generated by the action of SOD, must then be converted to $\mathrm{H}_{2} \mathrm{O}$ by other enzymes, such as ascorbateperoxidase (APX), catalase (CAT) and peroxidases (POD), since peroxide is also toxic when accumulated in plant.

The authors observed that in Chinese cabbage, CAT activities (Figure 2B) were lower in practically all saline treatments when compared to control. Watercress showed an increase in the

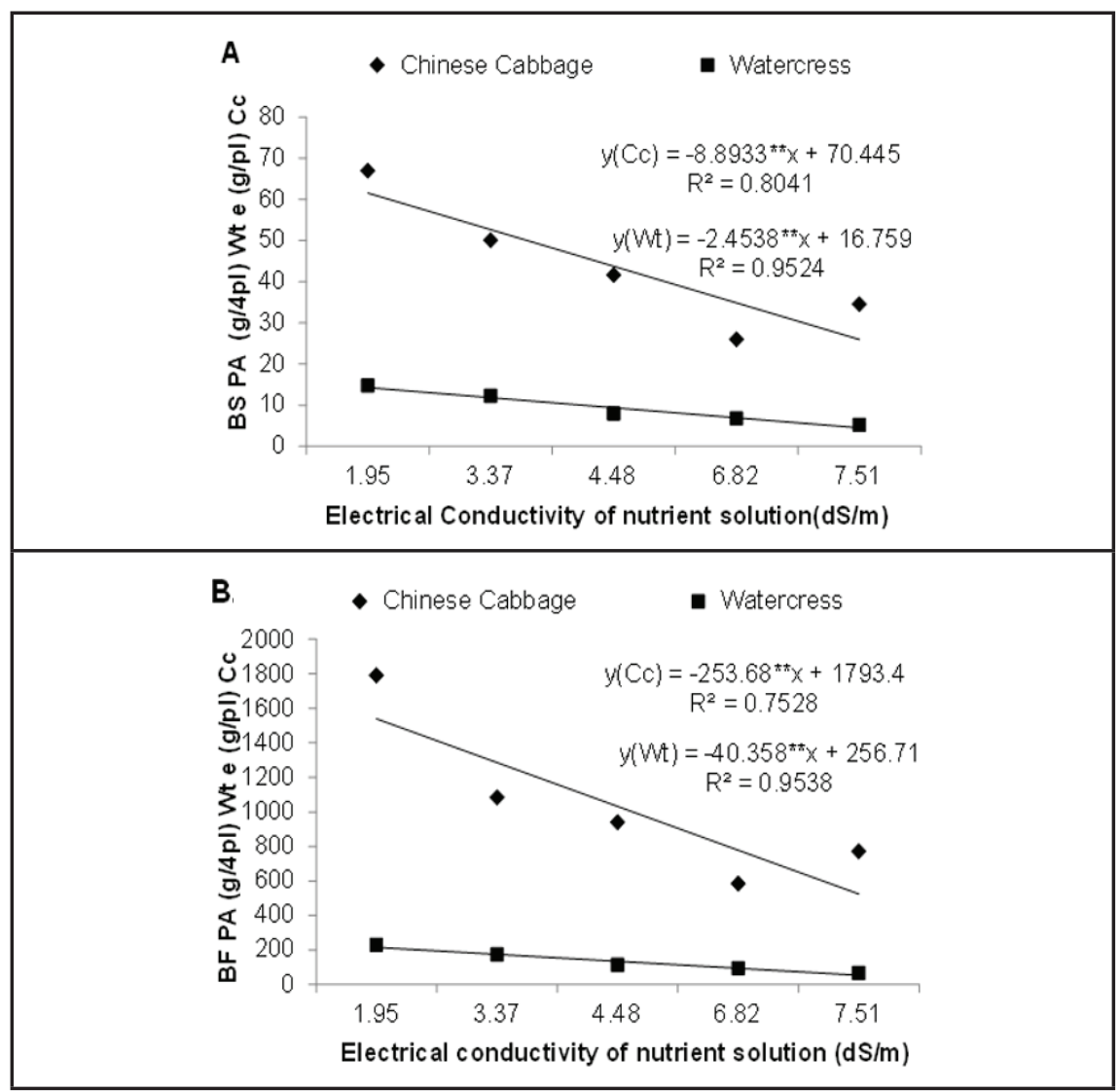

Figure 1. Dry (A) and fresh (B) shoot biomasses of watercress and Chinese cabbage cultivated under NFT hydroponic system in relation to salinity of the nutrient solution. Recife, UFRPE, 2012. 


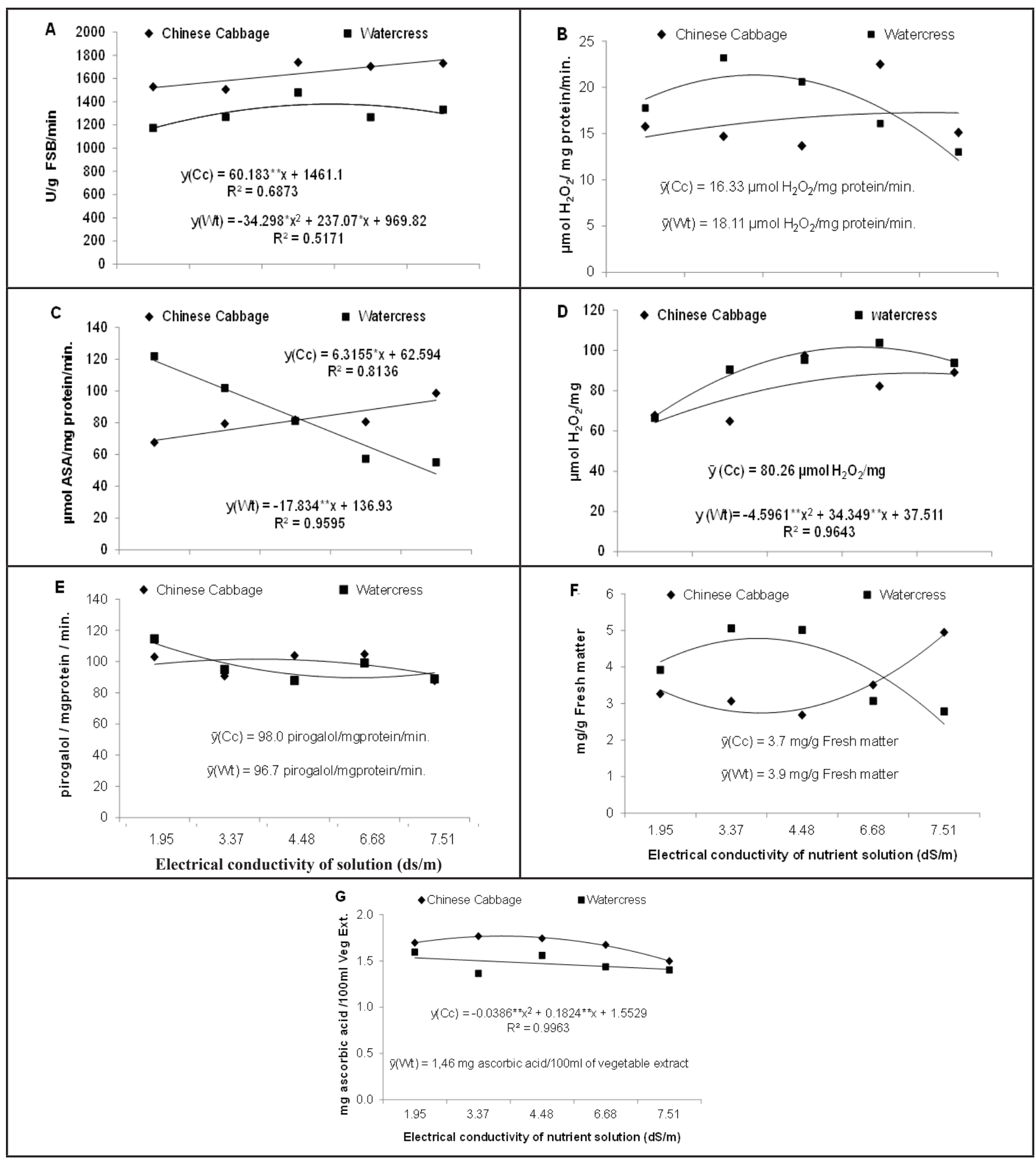

Figure 2. Activities of SOD (A), CAT (B), APX (C), POD (D), PPO (E), phenolic content (F), ascorbic acid content (G) of watercress and Chinese cabbage cultivated under hydroponic system in relation to the salinity of the nutrient solution. Recife, UFRPE, 2012.

activity of this enzyme in less severe saline treatments. In hydroponics cultivation of roquette, Jesus et al. (2015) observed an increased activity of CAT in the variety which is the most tolerant to an increase in salinity level of nutrient solution. Several other studies recorded higher activity of this enzyme in genotypes which showed to be the most tolerant to salt stress when compared with the ones which are the most sensitive (Sairan et al., 2002; Willadino et al., 2011).

The activity of APX (figure 2C) increased with increasing salinity in Chinese cabbage crop, whereas in watercress, a decrease was noticed. Increase of this enzymatic activity associated with an increase of SOD may promote a decrease of stress suffered by the plant. 
It is known that APX and CAT show different mechanisms of metabolizing $\mathrm{H}_{2} \mathrm{O}_{2}$ and that such enzymes act in different parts of plant cells. APXs are considered to be the most important enzymes in eliminating $\mathrm{H}_{2} \mathrm{O}_{2}$, both in cytosol and in chloroplasts (Barbosa et al., 2014).

Generally, the highest increase in the activity of APX characterizes varieties more tolerant to $\mathrm{NaCl}$ (Koca et al., 2007; Willadino et al., 2011). CAT is essential in removing $\mathrm{H}_{2} \mathrm{O}_{2}$ from photorespiration (Foyer \& Noctor, 2009), a characteristic process of plants that photosynthesize via $\mathrm{C} 3$, such as Chinese cabbage and watercress. The rate of elimination of $\mathrm{H}_{2} \mathrm{O}_{2}$ by CAT is much higher than that of APX, making CAT performance more important when hydrogen peroxide concentration is at higher levels (Barbosa et al., 2014).

In relation to the activity of POD (Figure 2D), both for watercress and for Chinese cabbage, the authors observed an increase in this activity with increasing salinity of nutrient solution, considering the values for the activity in watercress higher than in Chinese cabbage. Increase in peroxidase activity minimizes harmful effects of salt stress and, also, responds to fine regulation of the $\mathrm{H}_{2} \mathrm{O}_{2}$ concentration due to the great affinity for this ROS (Miller et al., 2010).

Activity of PPO was quite similar both for watercress and for Chinese cabbage (figure 2E). This enzyme catalyzes reaction of phenols (mono and diphenols) that involve oxygen, being considered useful in defense against oxidative stress induced by salinity (Agarwal \& Pandey, 2004); however, both for watercress and Chinese cabbage, this enzyme did not respond significantly to the imposed stress. Some species, such as roquette (Jesus et al., 2015), showed an increase in this enzyme activity when plants were submitted to salt stress.

The antioxidative defense system also includes non-enzymatic components. Phenols fall under this category because of their redox properties that play an important role in the neutralization and/or sequestration of free radicals
(Sousa et al., 2007). Their increase can be related to a plant mechanism to overcome oxidative stress caused by salinity. Although no significant effect on both cultures was noticed, phenolic content increased in watercress at less severe levels of salinity and Chinese cabbage at the two most saline levels (Figure 2F).

Considering non-enzymatic antioxidants, ascorbic acid (AA), also known as vitamin $C$, stands out because of its efficient action in capturing active oxygen species in the aqueous part of the cell, thus avoiding attack on the lipid membranes (Potters et al., 2002). Both for Chinese cabbage and for watercress, the authors noticed a little decrease in ascorbic acid content due to increased salt levels. Chinese cabbage showed invariably higher levels of vitamin $C$ than watercress (Figure $2 \mathrm{G}$ ), which suggests that this is an intrinsic characteristic of this variety.

In general, watercress did not show greater adaptation to saline stress. For adaptation strategies, a higher activity of POD stands out in plants under stress, ensuring fine regulation of $\mathrm{H}_{2} \mathrm{O}_{2}$, as well as keep the activity of CAT and phenolic content higher than the control in plants in the most saline treatments.

\section{REFERENCES}

AGARWAL, S; PANDEY, V. 2004. Antioxidant enzyme responses to $\mathrm{NaCl}$ stress in Cassia angustifolia. Biologia Plantarum 48: 555-560.

ALVES, MS; SOARES, TM; SILVA, LT; FERNANDES, JP; OLIVEIRA, MLA; PAZ, VPS. 2011. Estratégias de uso de água salobra na produção de alface em hidroponia NFT. Revista Brasileira de Engenharia Agrícola e Ambiental 15: 491-498.

ARAUJO, EBG; SÁ, FVS; OLIVEIRA, FA; SOUTO, LS; PAIVA, EP; NASCIMENTO, SMK; MESQUITA, EF; BRITO, MEB. 2016. Crescimento inicial e tolerância de cultivares de meloeiro à salinidade da água. Revista Ambiente \& Água 11: 462-471.

AYERS, RS; WESTCOT, DW. 1999. Qualidade da água na agricultura. Campina Grande: UFPB. 153p. (Estudos FAO: Irrigação e Drenagem, 29).

BARBOSA, MR; SILVA, MMA; WILLADINO, L; ULISSES, C; CAMARA, TR. 2014. Geração e desintoxicação enzimática de espécies reativas de oxigênio em plantas. Ciência Rural 44: 453-460.
BEZERRA NETO, E; BARRETO, LP. 2011. Análises químicas e bioquímicas em plantas. Recife: UFRPE, Editora Universitária da UFRPE. 267p.

EMBRAPA. 2011. December 2, 2011. Hortaliças: Agrião. Available at TTP://www.cnph. embrapa.br/páginas/dicas_ao_consumidor/ agriao.htm

EVANGELISTA, RM; VIEITES, RL; CASTRO, PS; RALL, VLM. 2009. Qualidade de couvechinesa minimamente processada e tratada com diferentes produtos. Ciência e Tecnologia de Alimentos 29: 324-332.

FERREIRA, ER; BEZERRA, LA; OLIVEIRA, TJSS; CARVALHO, JP; SILVA, RA. 2017. Benefícios do cultivo hidropônico em ambiente protegido. Revista Conexão Eletrônica 14: 485-491.

FOYER, CH; NOCTOR, G. 2009. Redox regulation in photosynthetic organisms: signaling, acclimation, and practical implications. Antioxid Redox Signal 11: 861-905.

FURLANI, PR. 1999. Hydroponic vegetable production in Brazil. Acta Horticulturae 481: 777-778.

GIANNOPOLITIS, CN; RIES, SK. 1977. Superoxide Dismutases: I. Occurrence in higher plants. Plant Physiology 59: 309-314.

JESUS, CG; CAMARA, TR; SILVA, FFE; WILLADINO, L. 2015. Production of rocket under salt stress in hydroponic systems. Horticultura Brasileira 33: 493-497.

KAR, M; MISHRA, D. 1976. Catalase, peroxidase, and polyphenoloxidase activities during rice leaf senescence. Plant Physiology 57: 315-319.

KOCA, H; BOR, M; OZDEMIR, F; TÜRKAN, I. 2007. The effect of salt stress on lipid peroxidation, antioxidative enzymes and proline content of sesame cultivars. Environmental and Experimental Botany 60: 344-351.

LIRA, RM; SILVA, EFF; SILVA, GF; SANTOS, AN; ROLIM, MM. 2015. Production, water consumption and nutrient content of Chinese cabbage grown hydroponically in brackish water. Revista Ciência Agronômica 46: 497-505.

MILLER, G; SUZUKI, N; CIFTCI-YILMAZ, S; MITTLER, R. 2010. Reactive oxygen species homeostasis and signalling during drought and salinity stresses. Plant, Cell and Environment 33: 453-467.

NAKANO, Y; ASADA, K. 1981. Hydrogen peroxide is scavenged by ascorbate-specific peroxidase in spinach chloroplasts. Plant Cell Physiology 22: 867-880.

POTTERS, G.; DE GARA, L.; ASARD, H.; HOREMANS, N. 2002. Ascorbate and glutathione guardians of the cell cycle, partners in crime? Plant Physiology and Biochemistry 40: 537-548.

RYANG, S; WOO, S; KWON, S; KIM, S; LEE, SH; KIM, K; LEE D. 2009. Changes of net photosynthesis, antioxidant enzyme activities, and antioxidant contents of Liriodendron tulipifera under elevated ozone. Photosynthetica 47: 19-25.

SAIRAN, RK; RAO, KV; SRIVASTAVA, GC. 
2002. Differential response of wheat genotypes to long-term salinity stress in relation to oxidative stress, antioxidant activity and osmolyte concentration. Plant Science 163: 1037-1046.

SANTOS, AN; SILVA, EFF; SILVA, GF; BARNABÉ, JMC; ROLIM, MM; DANTAS, DC. 2016. Yield of cherry tomatoes as a function of water salinity and irrigation frequency. Revista Brasileira de Engenharia Agrícola e Ambiental 20:107-112.

SANTOS, AN; SOARES, TM; SILVA, EFF; SILVA, DJR; MONTENEGRO, AAA. 2010. Cultivo hidropônico de alface com água salobra subterrânea e rejeito da dessalinização em Ibimirim, PE. Revista Brasileira de
Engenharia Agricola e Ambiental 14: 961-969.

SILVA, MG; SOARES, TM; GHEYI, HR; OLIVEIRA, IS; SILVA FILHO, JA. 2016. Crescimento e produção de coentro hidropônico sob diferentes densidades de semeadura e diâmetro dos canais de cultivo. Revista Irriga 21: 312-326.

SILVA, EN; SILVEIRA, JAG; FERNANDES, CRR; DUTRA, ATB; ARAGÃO, RM. 2009. Acúmulo de íons e crescimento de pinhãomanso sob diferentes níveis de salinidade. Revista Ciência Agronômica 40: 240-246.

SOUSA, CM; SILVA, HRE; VIEIRA JUNIOR, GM; AYRES, MCC; COSTA, CLS; ARAÚJO, DS; CAVALCANTE, LCD; BARROS, EDS; ARAÚJO, PBM; BRANDÃO, MS;
CHAVES, MH. 2007. Fenóis totais e atividade antioxidante de cinco plantas medicinais. Química Nova 30: 351-355.

TAIZ, L; ZEIGER, E. 2009. Fisiologia Vegetal. Porto Alegre: Artmed, 848p.

VIEIRA, IC; FATIBELLO FILHO, O. 1998. Flow injection spectrophotometric determination of hydrogen peroxide using a crude extract of zucchini (Cucurbita pepo) as a source of peroxidase. Analyst 123: 1809-1812.

WILLADINO, L; OLIVEIRAFILHO, RA; SILVA, EA; GOUVEIA NETO, AS; CAMARA, TR. 2011. Estresse salino em variedades de canade-açúcar: enzimas do sistema antioxidativo e fluorescência da clorofila. Revista Ciência Agronômica 42: 417-422. 